\section{South Florida rocked as dean quits over political funding}

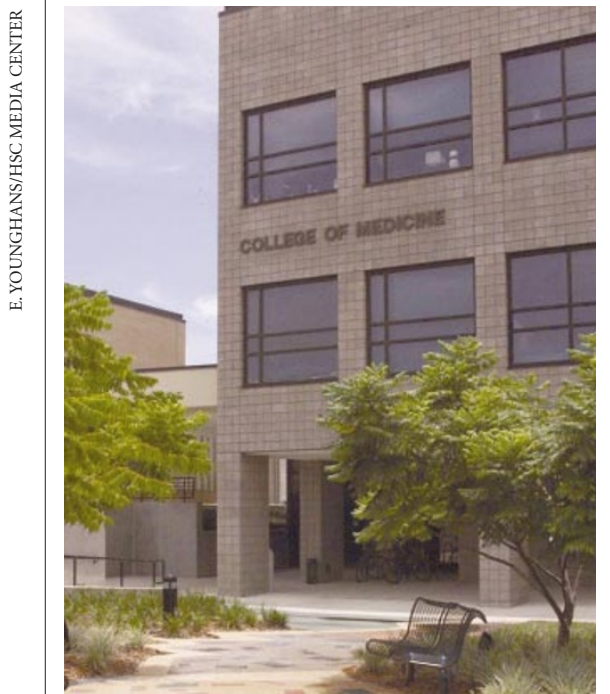

Beleaguered: the University of South Florida's medical college has been hit by resignations.

Rex Dalton, San Diego

Plans by the University of South Florida (USF) to enter the top league of US biomedical research institutions suffered another blow this month with the resignation of the dean of its medical school.

Robert Daugherty, who ran three medical colleges at the university, resigned on 13 October after admitting that he was raising money from faculty members to support a Florida state politician. The politician in question, Johnnie Byrd, has been instrumental in directing state funds towards the Tampa-based university.

The resignation is the latest in a series of setbacks for USF's expansion plans, which are part of a wider push by institutions in the the fourth most populous US state to punch their weight in biomedical research. Earlier this year, Michael Mullan, a prominent neuroscientist, resigned from USF after being accused of inappropriate behaviour with female staff. The resignation pushed a wealthy Alzheimer's research centre, led by Mullan, off the campus - along with a major federal grant to build a laboratory to study the genetic causes of drug addiction.

Mullan, who was a member of the team that discovered a gene linked to Alzheimer's disease (M. C. Chartier-Harlin et al. Nature 353, 844-846; 1991), was recruited by USF from Imperial College London in 1992. He resigned after a USF investigation concluded that he had sexually harassed one woman and created "a serious risk" of violating university policies in his pursuit of personal relationships with women in his lab.

The 25-page report quotes witnesses as saying that he ran his lab in a controlling manner like "a cult" — allegedly favouring those women with whom he was pursuing personal relationships. He allegedly threatened the career of one woman after their intimate relationship ceased, the report says.

In an interview, Mullan emphatically denied any impropriety. He called the USF report "absolute rubbish" and said that it was part of a plan by top officials to smear him.

After resigning in January, Mullan filed a civil lawsuit in Tampa against a former USF researcher whom he allegedly harassed in 1997. Mullan claims that Karen Gosche defamed him by commenting anonymously in a Tampa newspaper article about the USF report. On 13 October, a state judge rejected USF's request to dismiss this lawsuit, a move that may open the way for court-ordered testimony from women witnesses in the university's report.

USF attorney, Tom Gonzales, who represents Gosche, says that Mullan's lawsuit is an attempt to extract "revenge" on the university. Gosche, who is now a contract neuroscientist in Florida, says that USF produced an accurate and appropriate report. But she adds that she is disturbed at being legally threatened for cooperating with the inquiry.

The Alzheimer's institute headed by Mullan at USF left the campus with him. The Roskamp Institute is now based $30 \mathrm{~km}$ away in Sarasota, home of Robert Roskamp, the businessman and USF benefactor who contributed $\$ 5$ million to set up the centre. A laboratory to study genetic factors in drug addiction, to be supported by $\$ 5.85$ million from the White House Office of National Drug Control Policy, has also moved to Sarasota instead of to USF as originally planned.

Meanwhile, USF officials have been trying to establish a new Alzheimer's research institute. Byrd, the speaker of the Florida House of Representatives, last year helped to pass state

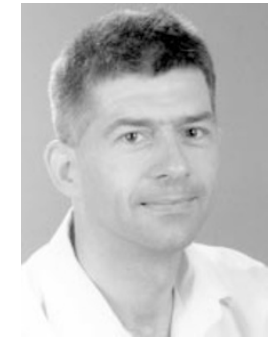

Michael Mullan resigned in January. legislation to provide $\$ 25$ million for this project, and he is supporting a proposal to provide another $\$ 45$ million for it next year.

But USF president Judy Genshaft demanded Daugherty's resignation after learning that he was trying to collect political contributions for Byrd from university employees. Daugherty couldn't be reached for comment; Byrd denies knowing of the fund-raising effort.

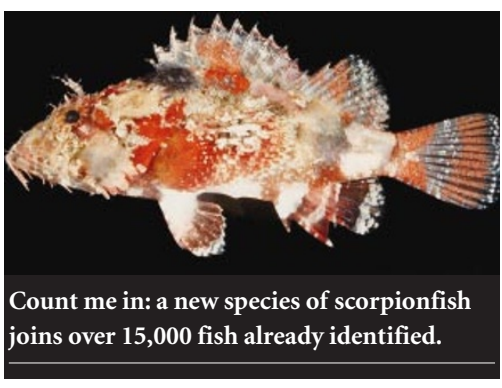

Marine survey sees net gain in number of fish species

Betsy Mason, Washington

There are some 20,000 different species of fish in the world's seas and oceans, about a quarter of which are still to be discovered and classified, says the first report of a census of marine life.

More than 300 scientists from 53 countries are working on the Census of Marine Life (COML), a ten-year, \$1-billion project due to be completed in 2010. Some 210,000 species of marine life have already been documented by the project, and more than $\mathbf{2}$ million are likely to be recorded eventually.

"New species are being discovered at the rate of about three a week," says Ron O'Dor of Dalhousie University, Canada, senior scientist for the COML. "Most of these species are coming from areas that haven't previously been explored."

The initiative is benefiting from technologies that allow scientists to explore new places and to see tiny or evasive creatures for the first time. "Every time a new technology is developed or an existing technology is refined, it opens up a new window on the ocean," says David Farmer of the University of Rhode Island, COML's lead scientist for technology.

The development of remotely operated submarines allows scientists to explore deeper and colder waters, such as the polar oceans and the Mid-Atlantic Ridge, and better sonar helps them to locate, track and even identify different fish species. The scientists are also using computer chips as electronic fish tags to track the movement of fish and record information such as heart rate and temperature.

In addition, researchers are using short sequences of DNA to help identify and catalogue species, particularly smaller ones such as plankton. "We hope that part of the census will include a DNA barcode for each new species," says Jesse Ausubel of Rockefeller University in New York. "This is something that would have been impossible just five years ago." 